\title{
A mosquito survey along a transect of urbanization in Dschang, West Region of Cameroon, reveals potential risk of arbovirus spillovers
}

Mayi Marie Paul Audrey ${ }^{1 \&}$, Bamou Roland ${ }^{1,2}$, Djiappi-Tchamen Borel'1,2, DjojoTachegoum Carelle ${ }^{1}$, Fontaine Albin ${ }^{3,4,5}$, Antonio-Nkondjio Christophe ${ }^{2}$, Tchuinkam Timoleon ${ }^{1}$

${ }^{1}$ Vector Borne Diseases Laboratory of the Applied Biology and Ecology Research Unit (VBID-URBEA), Department of Animal Biology, Faculty of Science of the University of Dschang. P.O. Box 067 Dschang, Cameroon.

'2aboratoire de Recherche sur le Paludisme, Organisation de Coordination pour la lutte Contre les Endémies en Afrique Centrale (OCEAC), Yaoundé, Cameroon

3Unité Parasitologie et Entomologie, Département Microbiologie et maladies infectieuses, Institut de Recherche Biomédicale des Armées, 19-21 Boulevard Jean Moulin, 13005 Marseille, France.

${ }^{4}$ Aix Marseille Univ, IRD, SSA, AP-HM, UMR Vecteurs - Infections Tropicales et Méditerranéennes (VITROME), Marseille, France.

${ }^{5}$ IHU Méditerranée Infection, Marseille, France.

\&corresponding author: MAYI Marie Paul Audrey; mayimariepaulaudrey@yahoo.com; Tel: (+237) 697230028.

\section{Abstract}

Background: With the advance of globalization and the decline of wild habitats, mosquito-borne viruses are no longer confined to their original sylvatic environments and are emerging or remerging worldwide. However, little is known about the mosquito species implicated in the spillovers of these viruses from their enzootic cycles. Method: We conducted an entomological field survey to catalogue the relative abundance of the Culicidae fauna in rural, peri-urban and urban areas in the Dschang locality in West Cameroon. Mosquitoes were collected from March-April and July-August 2019 at both aquatic and adult stages, and identified using stereomicroscopes and morphological identification keys. Results: A total of 1,401 mosquitoes belonging to 4 genera and 26 species were collected $(n=427,470$ and 504 in rural, peri-urban and urban areas respectively). The most abundant species Aedes africanus (45.47\%) as well as Culex moucheti (8.92 \%) were encountered in peri-urban and rural environments. Species like Culex duttoni (14.49\%), Culex 
quinquefasciatus (2.35\%) and Aedes aegypti (1.36\%) were solely found in urban area. Aedes albopictus (14.42\%), Culex (Culiciomyia) (6.57\%), Culex tigripes $(1.43 \%)$ and Eretmapodites chrysogaster $(0.64 \%)$ on the other hand were collected in the three study sites. Importantly, all these species have been suspected or incriminated as vectors of many arboviruses. Conclusion: This study identified potential sylvatic, urban and bridge-vectors that can play a role in current or future virus emergence in Cameroon. Further investigations are needed to assess if arboviruses are circulating in these areas and to study the vector role of each mosquito species in arbovirus transmission.

Keywords: Emerging diseases, vector-borne diseases, arboviruses, mosquitovectors, urbanization, Dschang

\section{Background}

Mosquito-borne viruses are becoming a serious public health problem worldwide as they spill over from their wild sylvatic habitat to emerge in many urban areas in all continents wherever competent vectors are present. Most of the major mosquitoborne viruses of medical importance that cause disease outbreaks in human populations without the requirement of amplification by a secondary non-human vertebrate host originated from the African continent (like Yellow fever virus, Chikungunya virus and Zika virus).

In a recent review, Braack and colleagues [1] listed 36 major arthropod-borne viruses (arboviruses) indigenous to Africa with their respective geographic distribution and known mosquito vector species. In Cameroon, the authors recorded many arboviruses, which include Dengue virus (DENV), Ntaya virus (NTAV), Spondweni virus (SPOV), Yaounde virus (YAOV) and Yellow fever virus (YFV) from the Flavivirus genus, Flaviviridae family; Chikungunya virus (CHIKV), Semliki Forest virus (SFV) and Sindbis virus (SINV) from the Alphavirus genus, Togaviridae family; Rift Valley Fever virus (RVFV) from the Phlebovirus genus, Bunyaviridae family; and Bunyamwera virus (BUNV), Bwamba virus (BWAV) and llesha virus (ILEV) from the Orthobunyavirus genus, Bunyaviridae family. These findings originate from many studies that have investigated the prevalence of arboviruses in Cameroon mainly based on the serodiagnostic of blood samples collected from humans [2-12]. However, few studies have investigated potential urban vectors or bridge vectors 
responsible for spillovers of these viruses from the forest into anthropized environments through entomological surveys $[2,13,14]$, and very few have searched for viruses in mosquitoes in Cameroon $[15,16]$.

To address this gap in knowledge, we made an up-to date catalogue of the diversity and abundance of mosquito species collected in three habitats along a transect of urbanization in Dschang, West Region of Cameroon. This survey would help to identify potential sylvatic, urban and bridge-vectors that can play a role in current or future virus spillover from wild to more urbanized areas. It is also an important initial step to assess the health risk of humans and animals living in these habitats to such diseases.

\section{Methods}

\section{Description of the study sites}

This study was carried out in rural (sylvatic), peri-urban and urban areas of Dschang Sub Division, within the Menoua Division. The rural and peri-urban habitats were located in Fonakeukeu (N: 05 24.48.1, E: 010 04.44.7) and Toutsang (N: 05 25.34.5, $E: 01004.10 .7)$ villages respectively while the urban habitat was located in the town of Dschang (N: 05 26.805, E: 010 03.8404). They all lie in the highland area of western Cameroon that exhibits a sub-tropical climate characterized by two seasons; a dry season of 4 months (from mid-November to mid-March) and a rainy season of 8 months (mid-March to mid-November). Annual average rainfall and temperature are of $321 \mathrm{~mm}$ and $21.6^{\circ} \mathrm{C}$ respectively [10]. The urban area (Dschang) is characterized by a shrub-like vegetation, an important hydrographic network and many artificial breeding sites, ideal to maintain the urban cycle of mosquitoes and their arboviruses. The peri-urban (Toutsang) and rural (Fonakeukeu) are found at about $2 \mathrm{~km}$ and $5 \mathrm{~km}$ respectively from the urban area (Dschang). Raffia palm bushes are common in these areas and are found along the valleys and streams which offer natural breeding sites that can easily maintain the sylvatic cycle of mosquitoes and their arboviruses. 


\section{Mosquito sampling and identification}

Field surveys were made in rural, peri-urban and urban areas during the rainy season from March-April and July-August 2019. Mosquitoes were collected in these areas three times per month at immature stages in available breeding sites (abandoned tires, riverbeds and floor pools) and at adult stages using sweep nets (to catch males, females and bloodfed females resting on the vegetation). Immature stages were reared to adults before identification. Morphological identification of species was done using stereomicroscopes and morphological identification keys [17-19].

\section{Results}

A total of 1,401 mosquitoes belonging to 4 genera and 26 species were collected in the three areas $(n=427$ in the rural area, $n=470$ in the peri-urban area and $n=504$ in the urban area) (Table 1). Out of the 26 species, Aedes africanus ( $n=637,45.47 \%$ ) were the most abundant, followed by Culex duttoni $(\mathrm{n}=203,14.49 \%)$, Aedes albopictus ( $\mathrm{n}=202,14.42 \%)$, Culex moucheti $(\mathrm{n}=125,8.92 \%)$ and Culex (Culiciomyia) $(\mathrm{n}=92,6.57 \%)$ (Table 1). Interestingly, Aedes africanus and Culex moucheti were only found in rural (Fonakeukeu) and peri urban (Toutsang) areas while Culex duttoni, Culex quinquefasciatus and Aedes aegypti were only found in urban area (Dschang). Species from the Culex Culiciomyia group, Eretmapodites chrysogaster group, Culex tigripes and Aedes albopictus on the other hand were caught in the three sites (rural, peri urban and urban). More importantly, all these species have been suspected or incriminated as vectors of many arboviruses (Table 1). 


\begin{tabular}{|c|c|c|c|c|c|c|}
\hline Mosquito species & $\begin{array}{l}\text { Rura } \\
\text { I } \\
\text { area }\end{array}$ & $\begin{array}{l}\text { Peri- } \\
\text { urban } \\
\text { area }\end{array}$ & $\begin{array}{l}\text { Urban } \\
\text { area }\end{array}$ & Total & $\begin{array}{l}\text { Potential vectors } \\
\text { for }\end{array}$ & References \\
\hline $\begin{array}{l}\text { Ae. } \\
\text { argenteopunctatus }\end{array}$ & 0 & 1 & 0 & 1 & $\begin{array}{l}\text { Nkolbisson virus } \\
\text { (YM 31.65), SFV }\end{array}$ & {$[16,31]$} \\
\hline Ae. circumluteolus & 1 & 1 & 0 & 2 & $\begin{array}{l}\text { SPOV, WESV, } \\
\text { NDUV, RVFV, } \\
\text { BUNV, Simbu virus, } \\
\text { MIDV }\end{array}$ & {$[22,27,28,34-37]$} \\
\hline Ae. aegypti & 0 & 0 & 19 & 19 & $\begin{array}{l}\text { YFV, DENV, ZIKV, } \\
\text { CHIKV, RVFV }\end{array}$ & {$[23,25,26,38,39]$} \\
\hline Ae. africanus & 316 & 321 & 0 & 637 & $\begin{array}{l}\text { YFV, ZIKV, BOUV, } \\
\text { BBKV, CHIKV, } \\
\text { WESV, WNV, } \\
\text { ORUV, BOZV }\end{array}$ & {$[16,20,40,41]$} \\
\hline Ae. albopictus & 7 & 1 & 194 & 202 & $\begin{array}{l}\text { DENV, CHIKV, } \\
\text { ZIKV, JEV, USUV, } \\
\text { YFV }\end{array}$ & {$[23-26,38,42,43]$} \\
\hline Ae. simpsoni & 0 & 1 & 1 & 2 & $\begin{array}{l}\text { YFV, BBKV, NRIV, } \\
\text { WESV }\end{array}$ & {$[16,29,40,44]$} \\
\hline Ae. $s p$ & 2 & 1 & 0 & 3 & & \\
\hline Ae. tarsalis group & 0 & 4 & 0 & 4 & $\begin{array}{l}\text { MIDV, WESV, } \\
\text { KEDV, PGAV, } \\
\text { PATV, ZIKV }\end{array}$ & {$[1,15,16,20]$} \\
\hline Ae. wellmani & 2 & 1 & 0 & 3 & Unknown & \\
\hline Ae. metallicus & 2 & 1 & 0 & 3 & YFV, ZIKV & {$[26,38]$} \\
\hline Ae. soleatus & 0 & 1 & 0 & 1 & Unknown & \\
\hline Aedes fraseri & 0 & 1 & 0 & 1 & & \\
\hline $\begin{array}{l}\text { Cx. (Culiciomyia) } \\
\text { group }\end{array}$ & 10 & 52 & 30 & 92 & NTAV, YAOV & {$[15,45]$} \\
\hline Cx. albiventris & 0 & 3 & 0 & 3 & NTAV, AMTV & {$[15,46]$} \\
\hline Cx. antennatus & 1 & 0 & 0 & 1 & $\begin{array}{l}\text { AMTV, BAGV, } \\
\text { SINV, USUV, } \\
\text { Acado virus }\end{array}$ & {$[21,47]$} \\
\hline Cx. duttoni & 0 & 0 & 203 & 203 & Arb11266 & [20] \\
\hline Cx. moucheti & 73 & 52 & 0 & 125 & NTAV & [15] \\
\hline Cx. philipi & 1 & 1 & 0 & 2 & Unknown & \\
\hline Cx.sp. & 1 & 11 & 0 & 12 & & \\
\hline Cx. tigripes & 1 & 5 & 14 & 20 & $\begin{array}{l}\text { NTAV, KAMV, } \\
\text { MOSV }\end{array}$ & {$[15,20,48]$} \\
\hline Cx. univittatus & 1 & 3 & 0 & 4 & $\begin{array}{l}\text { WNV, USUV, } \\
\text { WESV, SINV, } \\
\text { RVFV, SPOV }\end{array}$ & $\begin{array}{l}{[1,22,30,34,37,} \\
47]\end{array}$ \\
\hline Cx. wigglesworthi & 5 & 3 & 0 & 8 & Unknown & \\
\hline Cx. quinquefasciatus & 0 & 0 & 33 & 33 & $\begin{array}{l}\text { JEV, WNV, RVFV, } \\
\text { USUV }\end{array}$ & {$[21,22,40,42]$} \\
\hline Cx. pruina & 0 & 0 & 4 & 4 & Unknown & \\
\hline $\begin{array}{l}\text { Eretmapodites } \\
\text { chrysogaster group }\end{array}$ & 1 & 2 & 6 & 9 & $\begin{array}{l}\text { SFV, MIDV, NTAV, } \\
\text { Simbu virus, } \\
\text { Nkolbisson virus } \\
\text { (YM 31.65) }\end{array}$ & {$[15,16,49]$} \\
\hline $\begin{array}{l}\text { Coquelettidia } \\
\text { maculipennis }\end{array}$ & 3 & 4 & 0 & 7 & Unknown & \\
\hline Total & 427 & 470 & 504 & $\begin{array}{l}\text { Grand } \\
\text { Total= } \\
\mathbf{1 , 4 0 1}\end{array}$ & & \\
\hline
\end{tabular}




\section{Abbreviations}

Ae. Aedes; AMTV: Arumowot virus; BAGV: Bagaza virus; BBKV: Babanki virus; BOUV: Bouboui virus; BOZV: Bozo; BUNV: Bunyamwera virus; CHIKV: Chikungunya virus; Cx. Culex; DENV: Dengue virus; KAMV: Kamese virus; KEDV: Kedougou virus; MOSV: Mossuril virus ; MIDV: Middelburg virus; NDUV: Ndumu virus; NRIV: Ngari virus; NTAV: Ntaya virus; ORUV: Orungo virus; PATV: Pata virus; PGAV: Pongola virus; RVFV: Rift Valley fever virus; SFV: Semliki Forest virus; SINV: Sindbis virus; SPOV: Spondweni virus; USUV: Usutu virus; WESV: Wesselsbron virus; WNV: West Nile virus; YAOV: Yaounde virus; YFV: Yellow fever virus; ZIKV: Zika virus; Arb11266 unidentified Flavivirus related to WNV and Usutu virus

\section{Discussion}

This work aimed to catalogue the Culicidae fauna in urban, peri-urban and rural areas of Dschang, West Cameroon, that can be implicated as sylvatic, urban or bridge vectors in virus transmission. A high diversity of mosquito species was found in the locality with about $65.38 \%$ of the total mosquitoes collected identified as potential vectors of arboviruses (Table 1).

Aedes africanus was the most abundant mosquito species in rural and peri-urban areas. This species can transmit several arboviruses and has been incriminated as vector of YFV and CHIKV [20]. Culex duttoni, the second most abundant mosquito species found in the urban area, has been found to carry arboviruses like Arb11266 [20]. Culex quinquefasciatus, another species found exclusively in the urban area, has been reported to transmit West Nile Fever (WNV) [21] and RVFV [22]. Aedes albopictus is known vector of CHIKV [23] and has been suspected in Zika virus transmission in Gabon [24]. Culex Culiciomyia species and Culex moucheti were implicated in the transmission of NTAV [15].

Other mosquito species although collected in small numbers in our study area, have also been identified as vectors of many arboviruses. These are; Aedes aegypti, vectors of DENV, YFV, CHIKV [23, 25, 26]; Aedes circumluteolus, vectors of SPOV, RVFV, BUNV [27, 28]; Aedes metallicus, vectors of YFV [26]; Aedes simpsoni, vectors of YFV [29]; Culex univittatus, vectors of SINV [30]; Aedes argenteopunctatus, vectors of Nkolbisson virus (YM 31.65) and SFV [16, 31]. 
Interestingly, a high aggressiveness of mosquitoes was noted during sampling and few of the collected bloodfed mosquitoes (like Eretmapodites chrysogaster group, $C x$. moucheti and Ae. africanus) were found with human blood (Unpublished data).

Arboviruses that have been found circulating in Cameroon include DENV, YFV, CHIKV, Zika virus (ZIKV), ONNV (Onyong Onyong virus), NTAV, SPOV, Wesselsbron virus (WESV), SFV, SINV, Middelburg virus (MIDV), WNV, Tahyna virus (TAH), BUNV, Uganda S virus (UGSV), YAOV, RVFV, BWAV and ILEV [1, 2, 4, $6,8,9,12]$. However, few mosquitoes have been incriminated as potential vectors of these arboviruses in Cameroon. These few include; Aedes tarsalis group (viruses isolated: MIDV, WESV), Aedes argenteopunctatus (virus isolated: Nkolbisson (YM 31.65)), Aedes africanus (virus isolated: WESV), Aedes simpsoni (virus isolated: WESV), Culex albiventris (virus isolated: NTAV), Culex Culiciomyia (virus isolated: NTAV), Culex moucheti (virus isolated: NTAV), Culex tigripes (virus isolated: NTAV) and Eretmapodites chrysogaster group (viruses isolated: MIDV, Simbu virus) [15, 16].

Many mosquito species sampled in this study, such as Aedes africanus, Aedes aegypti, Aedes tarsalis, Aedes albopictus and Aedes metallicus, have been reported to be potential vectors of ZIKV and DENV in previous studies. Yet, ZIKV has been detected in Cameroon in Yaoundé [5, 9] and in the Fako Division [4]. Furthermore, a recent study found $11.7 \%$ and $10.4 \%$ of DENV circulating in Dschang and Bagangté respectively [10], all situated in the western highland. Another study revealed acute dengue in children living in urban and semi-urban areas of Dschang [32]. A mosquitobased arbovirus surveillance system might therefore help as a supplement to assess the presence of such arboviruses in the locality and in the whole country.

\section{Conclusion}

This study provides an up-to date catalogue of the Culicidae fauna along a transect of urbanization and identify the potential mosquito vectors that may be involved in arbovirus transmission in West Cameroon. Based on these preliminary findings, in addition to the recent detection of DENV in the locality, further researches are required to assess the prevalence of arboviruses in these areas and to study the vector role of these mosquito species in arbovirus transmission as well as to assess their anthropophily by blood meal source identification. A surveillance system based on the detection of pathogen genomic material in mosquito excreta has been recently 
developed [33]. This system is time and cost effective as compared to the standard method that relies on processing thousands of individual mosquitoes and would offer the opportunity to screen virus transmission in wider and wilder areas.

\section{List of Tables}

Table 1: Mosquito species collected in Dschang and potential vectors of arboviruses worldwide

\section{Competing interests}

The authors declare no competing interests.

\section{Authors' contributions}

Mayi Marie Paul Audrey, Bamou Roland, Djiappi-Tchamen Borel and Tchuinkam Timoleon, designed the study. Mayi Marie Paul Audrey, Bamou Roland, DjiappiTchamen Borel and Djojo-Tachegoum Carelle collected data in the field and analyzed themin the laboratory. All the authors drafted and revised the article for scientific and intellectual content. All the authors read and approved the final manuscript

\section{References}

1. Braack LA, Gouveia de Almeida P, Cornel AJ, Swanepoe R, De Jager C. Mosquito-borne arboviruses of African origin: review of key viruses and vectors. Parasites and Vectors. 2018; 11(29): 26

2. Demanou M, Antonio-Nkondjio C, Ngapana E, Rousset D, Paupy C, Manuguerra J-C, et al. Chikungunya outbreak in a rural area of Western Cameroon in 2006: a retrospective serological and entomological survey. BMC Res. Notes. 2010; 3(128): 1-7

3. Demanou M, Pouillot R, Grandadam M, Boisier P, Kamgang B, Herve JP, et al. Evidence of Dengue Virus Transmission and Factors Associated with the Presence of Anti-Dengue Virus Antibodies in Humans in Three Major Towns in Cameroon. PLOS Neglected Tropical Diseases. 2014; 8 (7): 1-100

4. Fokam EB, Levai LD, Guzman H, Amelia PA, Titanji VPK, Tesh RB, et al. Silent Circulation of Arboviruses in Cameroon. East African Medical Journal. 2010; 87(6): 262-268 
5. Gake B, Vernet MA, Leparc-Goffart I, Drexler JF, Gould EA, Gallian P, et al. Low seroprevalence of Zika virus in Cameroonian blood donors. Braz J Infect Dis. $2017 ; 21(4): 481-483$

6. Kuniholm MH, Wolfe ND, Huang CY-H, Mpoudi-Ngole E, Tamoufe U, Burke DS, et al. Seroprevalence and distribution of Flaviviridae, Togaviridae and Bunyaviridae arboviral infections in rural Cameroonian adults. Am. J. Trop. Med. Hyg. 2006; 74: 1078-1083

7. Krippner R, Von Lae G. First Confirmed Dengue-1 Fever Cases Reported from Cameroon. Journal of Travel Medicine. 2002; 9(5): 9:273-274

8. Peyrefitte CN, Rousset D, Pastorino BAM, et al. Chikungunya virus, Cameroon, 2006. Emerg. Infect. Dis. 2007; 13: epub

9. Salaun J-J, Brottes H. Les arbovirus au Cameroun: enquête serologique. Bull. Org. mond. Sante. 1967; 37: 343-361

10. Tchuandom SB, Tchouangueu TF, Antonio-Nkondjio C, Lissom A, Ngono Djang JO, Atabonkeng EP, Kechia A, Nchinda G, Kuiate JR. Seroprevalence of dengue virus among children presenting with febrile illness in some public health facilities in Cameroon. Pan African Medical Journal. 2018; 31(177): 111

11. Tchuandom SB, Tchadji JC, Tchouangueu TF, Zambo Biloa M, Atabonkeng ET, Fumba MIM, et al. A cross-sectional study of acute dengue infection in paediatric clinics in Cameroon. Biomed Central Public Health. 2019; 19(958): 1-7

12. Yousseu FBS, Nemg FBS, Ngouanet, SA, Mekanda FMO, Demanou M. Detection and serotyping of dengue viruses in febrile patients consulting at the New-Bell District Hospital in Douala, Cameroon. PLoS ONE. 2018; 13(10): 113

13. Fontenille D, Toto JC. Aedes (Stegomyia) albopictus (Skuse), a potential new dengue vector in Southern Cameroon. Emerg. Infect. Dis. 2001; 7: 1066-1067

14. Paupy C, Ollomo B, Kamgang B, Moutailler S, Rousset D, Demanou M, et al. Comparative role of Aedes albopictus and Aedes aegypti in the emergence of dengue and chikungunya in Central Africa. Vector-borne and Zoonotic Diseases. 2009; 0: 1-8 
15. Brottes H, Rickenbach A, Bres P, Salaun J-J, Ferara L. Les arbovirus au Cameroun : isolements à partir de moustiques. Bull. Org. mond. Santé. 1966 ; $35: 811-825$

16. Salaun JJ, Rickenbach A, Bres P, Brottes H, Germain M, Eouzan J-P, et al.

Les arbovirus isolés à partir de moustiques au Cameroun. Bull.World HIth.

Org. 1969; 41: 233-241

17.Edwards FW. Mosquitoes of the Ethiopian region: III Culicine adults and pupae. London : British Museum (Natural History).1941 ; 3 : p 499

18.Jupp, P.G. Mosquitoes of southern Africa: Culicinae and Toxorhynchitinae. Hartebeesspoort (South Africa). Ekogilde publishers. 1996; p155.

19.Service MW. Handbook to the Afrotropical Toxorhynchitine and Culicine Mosquitoes, Excepting Aedes and Culex. British Museum (Natural History), London. 1990.

20.Saluzzo JF, Vincent T, Miller J, Veas F, Gonzalez JP. Arbovirus Discovery in Central African Republic (1973- 1993): Zika, Bozo, Bouboui, and More. Ann Infect Dis Epidemiol. 2017; 2(3): 1022

21. Ndiaye EL, Diallo D, Fall G, Ba Y, Faye O, Dia, I, et al. Arboviruses isolated from the Barkedji mosquito-based surveillance system, 2012-2013. BMC Infectious Diseases. 2018; 18(642): 1-14

22.Sang R, Kioko E, Lutomiah J, Warigia M, Ochieng C, O'Guinn M, et al. Rift Valley fever virus epidemic in Kenya, 2006/2007: the entomologic investigations. Am J Trop Med Hyg. 2010; 83(2):28-37

23.I-Ching S, Kummerer BM, Yoke-Fun C, Roques P, Drosten C, AbuBakar S. Updates on chikungunya epidemiology, clinical disease, and diagnostics. Vector Borne Zoonotic Dis. 2015; 15(4): 223-30

24. Grard G, Caron M, Mombo IM, Nkoghe D, Ondo SM, Jiolle D, et al. Zika Virus in Gabon (Central Africa) - 2007: A New Threat from Aedes albopictus? PLOS Neglected Tropical Diseases. 2014; 8(2): 1-6

25. Diallo M, Sall AA, Moncayo AC, Ba Y, Fernandez Z, Ortiz D, et al. Potential role of sylvatic and domestic African mosquito species in dengue emergence. Am J Trop Med Hyg. 2005; 73(2):445-9.

26. Huang Y-LS, Higgs S, Horne KM, Vanlindingham DL. Flavivirus-mosquito interactions. Viruses. 2014; 6:4703-30 
27. Karabatsos N. International Catalogue of Arthropod-borne Viruses, American Society for Tropical Medicine and Hygiene, San Antonio, Texas. 1985 ; 3(1) : $137-152$

28. Kokernot RH, Heymann CS, Muspratt J, Wolstenholme B. Studies on arthropod-borne viruses of Tongaland. V. Isolation of Bunyamwera and Rift Valley fever viruses from mosquitoes. S Afr J Med Sci. 1957b; 22: 71-80

29. Strode GK. Yellow Fever. Mc Graw-Hill, New York, 1951

30. Taylor RM, Hurlbut HS, Work TH, Kingston JR, Frothingham TE. Sindbis virus: a newly recognized arthropod-transmitted virus. Am J Trop Med Hyg. 1955; 4:844-62 173.

31. Mclntosh BM, Worth CB, Kokernot RH. Isolation of Semliki Forest virus from Aedes (Aedimorphus) argenteopunctatus (Theobald) collected in Portuguese East Africa. Trans R Soc Trop Med Hyg. 1961b; 55(2):192-8

32. Tchuandom SB, Tchadji JC, Tchouangueu TF, Biloa MZ, Atabonkeng EP, Fumba MIM, et al. A cross-sectional study of acute dengue infection in paediatric clinics in Cameroon. BMC Public Health. 2019; 19: 958

33. Fontaine A, Jiolle D, Moltini-Conclois I, Lequime S, Lambrechts L. Excretion of dengue virus RNA by Aedes aegypti allows nondestructive monitoring of viral dissemination in individual mosquitoes. Scientific Reports. 2016; 6(24885): 110

34. Kokernot $\mathrm{RH}$, Smithburn KC, Paterson HE, De Meillon B. Further isolations of Wesselsbron virus from mosquitoes. SAMJ. 1960a; 87: 1-4

35. Kokernot RH, Mclntosh BM, Worth CB. Ndumu virus, a hitherto unknown agent, isolated from culicine mosquitoes collected in northern Natal, union of South Africa. Am J Trop Med Hyg. 1961a; 10(3): 383-6

36. Weinbren MP, Heymann CS, Kokernot RH, Paterson HE. S. Afr. J. med. Sci. 1957; $22: 93$

37. Worth BC, Paterson HE, De Meillon B. Amer. J. trop. \& fed. Hyg, 1961; 10: 583-592

38. Petersen LR, Jamieson DJ, Powers AM, Honein MA. Zika virus. N Engl J Med. 2016; 374: 1552-63

39. Linthicum KJ, Davies FG, Kairo A, Bailey CL. Rift Valley fever virus (family Bunyaviridae, genus Phlebovirus): isolations from Diptera collected during an inter-epizootic period in Kenya. J Hyg (Lond). 1985; 95: 197-209 
40. Ochieng C, Lutomiah J, Makio A, Koka H, Chepkorir E, Yalwala S, et al. Mosquito-borne arbovirus surveillance at selected sites in diverse ecological zones of Kenya; 2007-2012. Virol J. 2013; 10:140

41. Dick GW, Kitchen SF, Haddow AJ. Zika virus. 1. Isolations and serological specificity. Trans R Soc Trop Med Hyg. 1952; 46:509-20

42. Sucharit SK, Surathin SRS. Vectors of Japanese encephalitis virus (JEV): species complexes of the vectors. Southeast Asian J. Trop. Med. Public Health. 1989; 20(4): 611-621.

43. Nikolay B, Diallo M, Faye O, Boye CS, Sall AA. Vector competence of Culex neavei (Diptera: Culicidae) for Usutu virus. Am J Trop Med Hyg. 2012; 86(6): 993-6

44.Zeller HG, Diallo M, Angel G, Traoré-Lamizana M, Thonnon J, Digoutte JP. Ngari virus (Bunyaviridae: Bunyavirus). First isolation from humans in Senegal, new mosquito vectors, its epidemiology [in French]. Bull Soc Pathol Exot. 1996; 89: 12-6

45. Williams RAJ, Vazquez A, Asante I, Bonney K, Odoom S, Puplampu N, et al. Yaounde-like virus in resident wild bird, Ghana. Afr J Microbiol Res. 2012; 6(9): 1966-9

46. Berthet N, Nakoune E, Gessain A, Manuguerra JC, Kasanji M. Complete genome characterization of the Arumowot virus (unclassified Phlebovirus) isolated from Turdus libonyanus birds in the Central African Republic. Vector Borne Zoonotic Dis. 2016; 16(2): 139-43

47. Mossel EC, Crabtree MB, Mutebi JP, Lutwama JJ, Borland EM, Powers AM, et al. Arboviruses Isolated from Mosquitoes Collected in Uganda, 2008-2012. Journal of Medical Entomology. 2017; 54(5):1403-1409

48. Centres for Disease Control and Prevention. Kamese Virus. https://wwwn. cdc.gov/arbocat/VirusDetails.aspx?ID=223\&SID=7. 2017

49. MacNamara FN. Aim. trop. Med. Purasif. 1953; 47:9 